\title{
Effect of protamine and Its abnormalities on male fertility potential
}

\section{Tahereh Rahiminia $^{1}$, Javad Amini Mahabadi ${ }^{2}$, Ehsan Farashahi Yazd ${ }^{3}$, Alireza Talebi ${ }^{4}$}

1. Assistant Professor, Gametogenesis Research Center, Shahid Beheshti Hospital, Kashan University of Medical Sciences, Kashan, Iran., (Corresponding Author), Tel: +98-31-55621158, Email: tahereh.rahiminia@gmail.com. ORCID ID: 00000002-4320-0892

2. Ph.D. of Reproductive Biology, Gametogenesis Research Center, Kashan University of Medical Sciences, Kashan, Iran. ORCID ID: 0000-0003-2930-1213

3. Assistant Professor, Stem Cell Biology Research Center, Yazd Reproductive Sciences Institute, Shahid Sadoughi University of Medical Sciences, Yazd, Iran. ORCID ID: 0000-0003-1122-0626

4. Assistant Professor, Yazd Reproductive Sciences Institute, Shahid Sadoughi University of Medical Sciences, Yazd, Iran. ORCID ID: 0000-0001-7753-0710

\section{ABSTRACT}

Background and Aim: All studies on mammals and rodents have revealed the presence of protamine $1(\mathrm{P} 1)$ and protamine $2(\mathrm{P} 2)$ in the sperm which is indicative of the expression of these two genes at different molecular levels. The aim of this study was to investigate the effect of protamine and its disorders on male fertility potential.

Materials and Methods: Using keywords of sperm, protamine, male infertility, and chromatin we searched PubMed and Google Scholar databases between 1980 and 2020.

Results: Sperm concentration, motility, and morphology in the patients with variable P1/P2 ratios were significantly reduced compared to those in the individuals with normal P1/P2 ratios which were directly associated with reduced fertility rate. The most common protamine abnormality in the infertile men was increased $\mathrm{P} 1 / \mathrm{P} 2$ ratio which was frequently associated with a decreased level of P2 and increased level of P2 precursors. Increased levels of histone B2 (H2B) in sperm and lower levels of protamine have been reported. Any disturbances in the histone expression process cause inconvenient early chromatin condensation, transcription arrest, as well as spermatogenesis failures.

Conclusion: The results of this study showed that the protamine transcripts ratio can be used as a marker for male fertility. Histones/protamines mRNAs ratios are important for sperm quality and therefore can be used as predictors for male infertility. Altered levels of protamines may result in an increased susceptibility to injury in the sperm DNA causing infertility or poor outcome in assisted reproduction.

Keywords: Male infertility, Sperm, Protamine, Chromatin

Received: July 6, $2019 \quad$ Accepted: Aug 8, 2020

How to cite the article: Tahereh Rahiminia, Javad Amini Mahabadi, Ehsan Farashahi Yazd, Alireza Talebi. Effect of protamine and Its abnormalities on male fertility potential. SJKU 2020;25(5):52-66.

Copyright (C) 2018 the Author (s). Published by Kurdistan University of Medical Sciences. This is an open access article distributed under the terms of the Creative Commons Attribution-Non Commercial License 4.0 (CCBYNC), where it is permissible to download, share, remix, transform, and buildup the work provided it is properly cited. The work cannot be used commercially without permission from the journal 


\section{اثر بروقامين و اختلالات آن در بِتانسيل بارورى مردان}

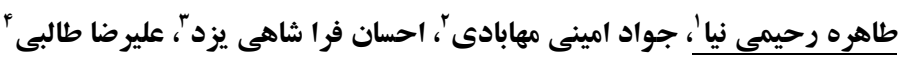

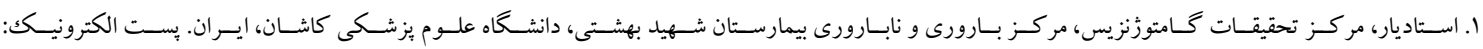

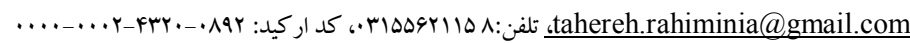

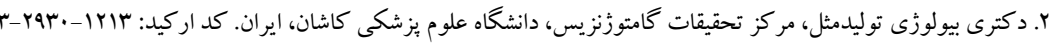

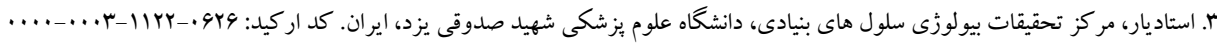

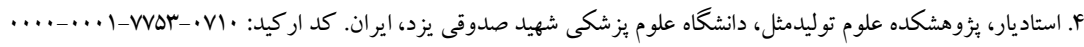

حكي4ه

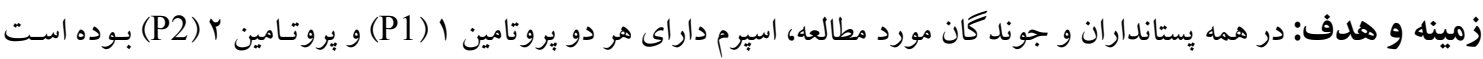
كه نشان دهنده بيان اين دو زن در سطوح مختلف مولكولى است. هـدف از ايسن مطالعـه، بررسى اثر برووتـامين و اخـتلالات آن در يتانسيل بارورى مردان است.

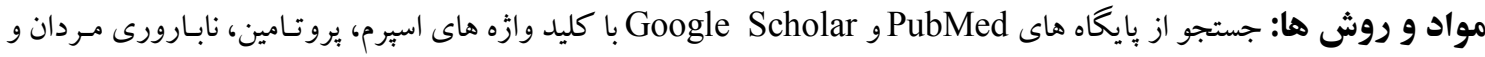

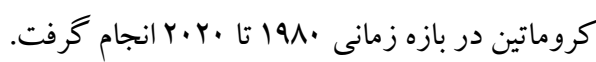
يافته ها: غلظت، تحر كك و مورفولوزى اسيرم در بيماران با نسبت هاى متغيرى از P1 به P2 در مقايسه با افر اد با نسبت طبيعى P1 بـــ كاهش قابل توجهى يافته است كه ارتباط مستقيمى با كاهش توانايى بارورى دارد. رايجترين اختلال يروتامين در مردان نابـارور افزايش نسبت P1 به P2 است كه اغلب در نتيجه كاهش سـطح يـروتئين P2 هـمزمـان بـا افز ايش سطح يسيش سـازهاى P2 اسـت. افزايش سطح هيستون (H2B) B2 با سطوح كمتر يروتامين گزارش شده است. هر گونه اختلال در فر آيند بيان هيستون سبب تراكم

$$
\text { ناهمسان اوليه ى كروماتين، توقف رونو يسى و همجِنين نقص در اسبرماتوزنز مى شود. }
$$

نتيجه كيرىى: نتايج اين مطالعه نشان داد كه نسبت رونويسى برووتامين به عنوان يكك نشـانگر بـراى بـارورى مـردان عمـل مسى كنــ. نسبت mRNA هاى هيستون/يرو تامين براى كيفيت اسبرم مهم هستند و بنابراين مى تو انند به عنوان بيش بينى كننده هـاى نابـارورى مردان استفاده شوند. تغيير سطح يرو تامين ها منجر به افزايش حساسيت به آسيب در DNA اسبرم مى شـوند كـه سـبب نابـارورى يـا نتايج ضعيف در توليد مثل مى گردند. كليد وازه ها: نابارورى مردانه، اسبرم، يروتامين، كروماتين

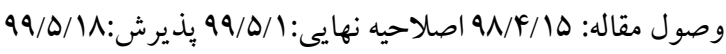


روى مراحل تكامل اسِرم در روند بارورى نقش داشته باشند

اسيرم زايى بِتانداران يكك فرآيند منحصربه فرد يِيجيدهاى

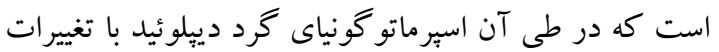
فيزيولوزيكى و بيوشيميايى و مورفولوزيكى به اسبرماتوزو آى هايلو ييد تمايز يافته با يكك هسته فشرده وآكروزوم و دم تبديل

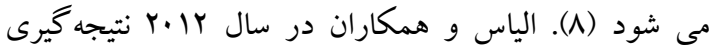
نمودند كه كمبود يروتامين منجر به كاهش باندهاى دى سولفيدى شده و اين امر منجر به عدم حفاظت از DNA اسيرم

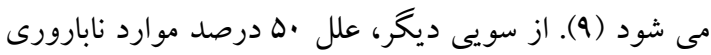
مربوط به فاكتورهاى مردانه است كه در اين بين •r درصد

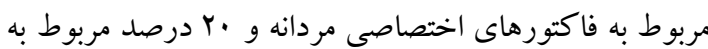
فاكتورهاى اختصاصى در هر دو جنس است (·(). در وهلهى

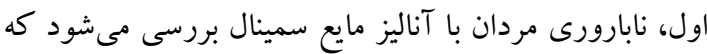

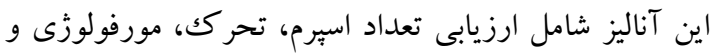
ناهنجارىهاى آن است كه اطلاعات ارزندهاى از وضعيت بارورى فرد در اختيار قرار مىدهد. اين ارزيابىها بسيارى از

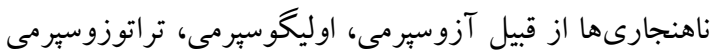

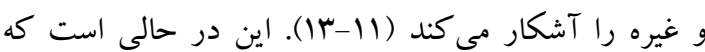
بسيارى از مطالعات سال هاى اخير به اين نتيجه رسيدند كه

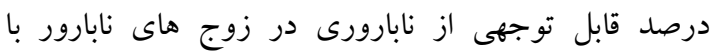

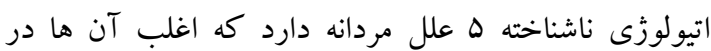

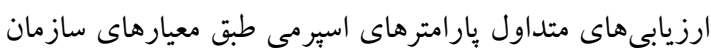

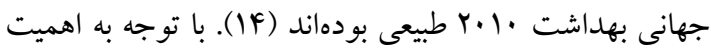

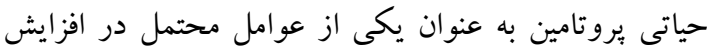
بروز نابارورى مردانه، اين مطالعه مرورى با هدف بررسى بهى

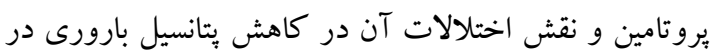

$$
\text { مردان انجام شده است. }
$$

\section{مواد و روش ها}

اين مطالعه مرورى حاصل بخشى از بايان نامـه دكترى و در

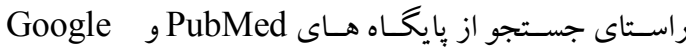

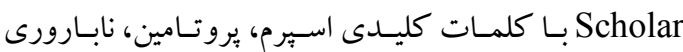

مقدمه

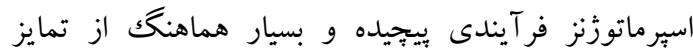
سلولهاى بنيادى اسيرماتو گونى به اسبرم بالغ در بزر كسالان لتهان است. يكى از ويزگىهاى اصلى تمايز سلولهاى زاياى مردانه روند ترتيبى، ساختارى و سازماندهى مجدد فضايى كروموزوم است كه در رويدادهاى متفاوتى به عنوان باز آرايى كروماتين، نوتر كيبى DNA، حر كات ديناميك كروموزوم و دومينهاى آن (سانترومرها و تلومرها) در هسته تظاهر مى يابد (1) - (1). هيستونها در مراحل نهايى بلوغ اسبرماتيد به ترتيب توسط

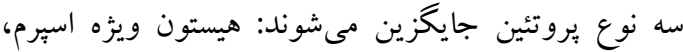

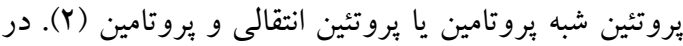

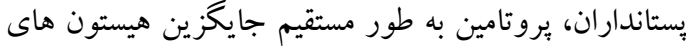
سوماتيك نمىشود؛ به جاى آن اسبرماتيد در حال تمايز يكى

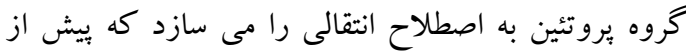

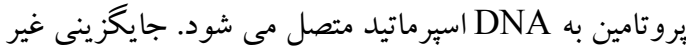
طبيعى هيستون ها توسط يروتامين ها مى تواند سبب قطعه قطعه شدن DNA اسبرم شود و به همين علت، بين كيفيت كروماتين اسبرم و آسيب DNA رابطه وجود دارد (r). بررسى مقايسهاى سه خانو اده بروتئين ذكر شده نشان مى دهد كه فر آيند آمادهازى زنوم اسيرم براى لقاح احتمالاً تكامل تخصصى اسيرم از هيستونها به بروتئين شبه بروتامين و به

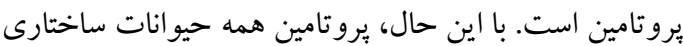

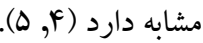
بروتامين يكك يروتئين اصلى شناخته شده اسيرم است كه به DNA اسبرم متصل مى شود و به عنوان ماركرهاى مولكولى بارورى در نظر گرفته مى شود. در طى فر آيند

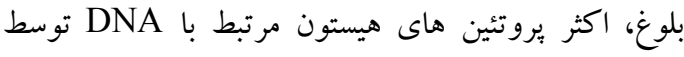
يروتامين ها جايخزين مى شوند (9). بائو و همكاران در سال

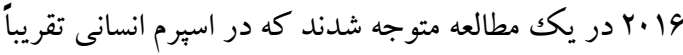

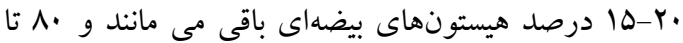

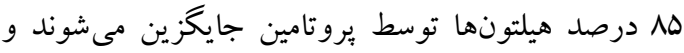
مشخص گرديد كه عوامل ابى زنتيكى مى تواند با اثر بر فئر 
بالاى آمينواسيدهاى بار منفى در مقايسهـ بـا محتواى بـالاى

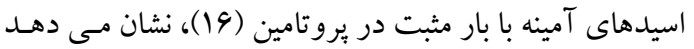

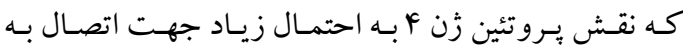

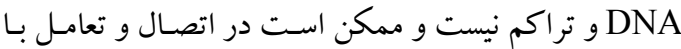

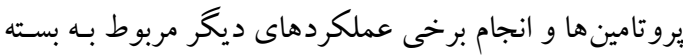
بندى كروماتين باشد (IV). در حالى كه زن P1 بـه نظر مى لئ رسد در اسبرماتيد تمامى بِستانداران رونويسى و ترجمه شـود

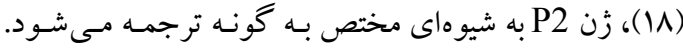
تكنيككهاى PCR حضسور P1 را در طيف گسـتردهاى از بستانداران تكامل يافته تاييد كرده اند؛ اما تلاش بـراى تكثير توالى P2 نشان داد كه زن P2 تنوع قابل توجهى دارد (19).

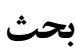
تغييرات پِس از ترجمه در يروتامين:

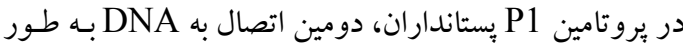
معمول شامل يكك يا جند جايگاه فسفوريلاسيون است. اين سايتها در انسان، اسب و كاو شناسايى شده است و بـه نظر مى رسد بلافاصله هـس از سـنتز هـروتئين و نيـز پِس از ورود اسبرم به تخمك فسـوريله شـوند. در P2، فرم بـيش سـاز و همجِين اشكال مختلف يُردازش شـده فسفريله مسى باشـند (19). جايخـاه هـاى فسفوريلاسـيون اغلـب شـامل سـرين و ترئسونين اسـت، اخـر جـه در مـوش تيـروزين هـم فسـفوريله

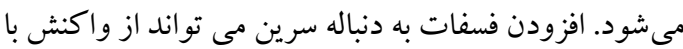
DNA

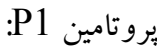

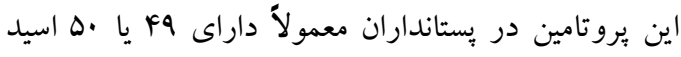
آمينه و شامل سه دومين است. دومين مركزى كه در اتصال به DNA نقش دارد، غنى از آرزنين و در هر دو طرف دهرين حاوى سيستئين است. در اغلب گونه ها، دومين مركزى به اله طور معمول از يك سرى توالى حاوى بـ تا لال آرزنين كه هـ بروتئين را به DNA متصل مى كند، تشكيل شده است. مقايسه توالى برو تامين ماهى با برو تامين P1 بستانداران نشان

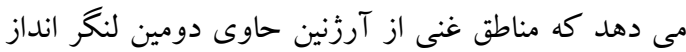

مردان و كروماتين بر اساس MESH در بازه زمانى •194 تا

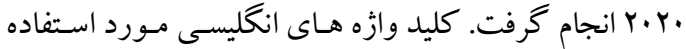
Male infertility, Sperm, Protamine, " شـامل Chromatin ها ابتدا عناوين تمام مقالات به دست آمـده بررسى و مـوارد

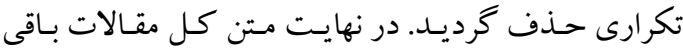
مانـده بررسى و مطالب مـرتبط بـهـ زن برو تـامين؛ سـاختار و

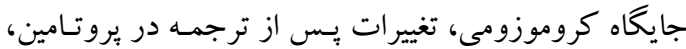

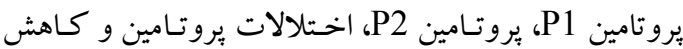

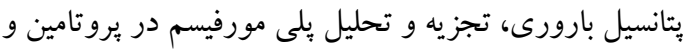
زُن هاى مر تبط بـا آن، نو كلئوهيستون در سـاختار كرومـاتين

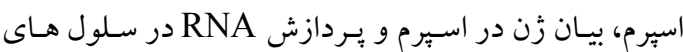
زايا و تأثير اين عوامل بر بِتانسيل بارورى مـردان از مطالعات

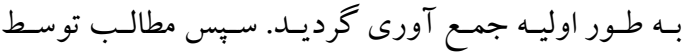

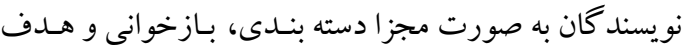

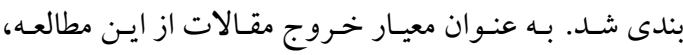

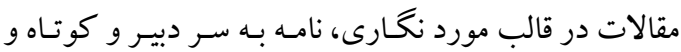

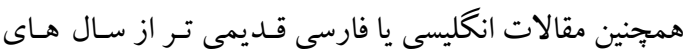
. 194 ميلادى از ليست مطالعات مورد بررسى خارج شدند.

\section{يافته ها}

زُن يروتامين؛ ساختار و جايخحاه كرومـوزومى: زنهـاىP1 و

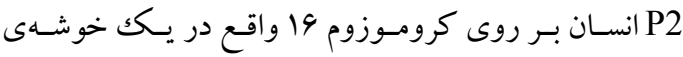

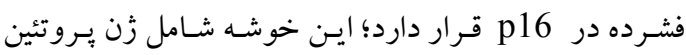
انتقالى ب نيز است كـه آن هـم در تراكم كرومـاتين دخالت دارد. خوشه يروتامين مشابهى نيز بـر روى كرومـوزوم 19 در

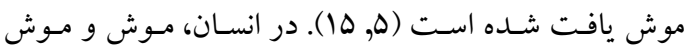

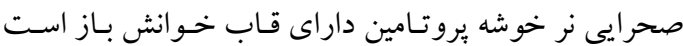

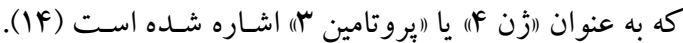
توالى آمينواسيد بيش بينى شده براى اين بـروتئين، تقريباً بـهـ

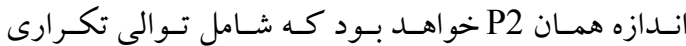
كلوتاميكك و اسيد اسيارتيكك و نيز خوشه آرزنين و ليزين در دومين متصل به DNA است. اين تفاوت در تركيب محتواى 
كروههاى تيول سيستئين در بروتامين اكسيد مى شوند و باند

دى سولفيد شكل مى دهند، از بين مى رود (צ) (צ). اختلالات يُروتامين و كاهش بِتانسيل بارورى:

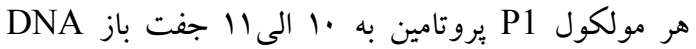
متصل مىشود. يروتامين P2 به بخشى كمى بزركت تر از DNA منفى امتداد ستون فسفو دى استر DNA را خنثى و مولكول را قادر مى سازد تا فشرده شود. كميلكس DNA و بروت تامين در اسيرم پِستانداران تكامل يافته، تشكيل شبكهاى از بيوندهاى دى سولفيد مى دهد كه اكثريت زن هاى

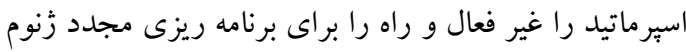

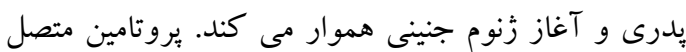

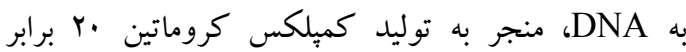
كوجكتر از هسته سوماتيك مىشود. اين كمبلكس به به به بله هيدروديناميك بيشتر سر و البته به طور غير مستقيم به شكل فئل سر كمك مى كند. مشاهده شده است كه اسبرم حاوى بسته بندى نادرست كروماتين اغلب بزركى شده و يا سر با فالها

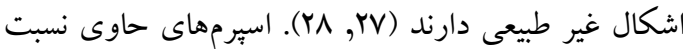
بالاترى از P2 (انسان و همستر) نسبت به اسبرمهاى حاوى

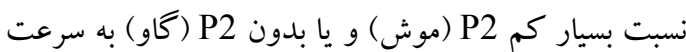
در تخمكك از تراكم خارج مى شوند. اين امر نشان مى دهد

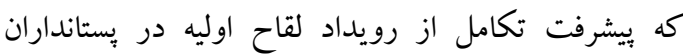

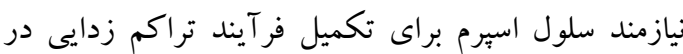
يكك دوره خاص زمانى بس از ورود به تخمك است و اين زمان در ميان گونههاى مختلف متفاوت مى باشد. تفاوت در

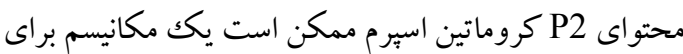

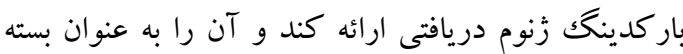
قابل قبول يا غير قابل قبول مورد شناسايى قرار دهد (ه). به به اله

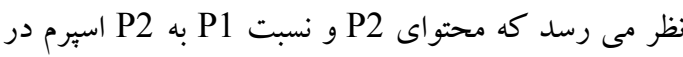
يك كونه به شدت تنظيم شده باشد؛ اما به طور جشمخيرى بين گونهها متفاوت است. اين موضوع ممكن است توضيح

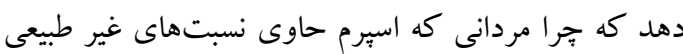
از P1 و P2 دارند، نابارور هستند (Ya).
حفاظت شده اند (حدود .9 تا •1 درصد شباهت توالى)؛ اما باقى مانده تو الى يروتئين تنوع قابل توجهى دارد (Y).

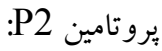
در حالى كه به نظر مى رسد بِروتامين P1 و P2 از يك ماده بيش اجدادى مشترك مشتق شده اند؛ اما بروتامين P2 داراى ويز گیىهاى متعددى است كه از P1 متمايز است. در

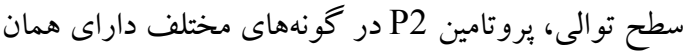

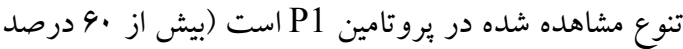

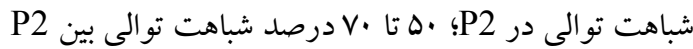

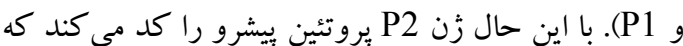
به DNA اتصال مى يابد و سبّ مراحل يروتئوليتيكك راطى مى كند (Yr). اين رويداد يُردازش در طى يكك دوره جֶند روزه در اواخر اسيرماتيد رخ مى دهد و نتيجه آن توليد شش تش

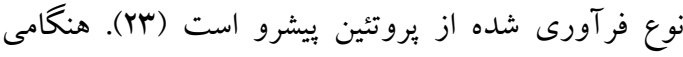
يردازش كامل مى شود كه حدود •F درصد از بايانه آمينى

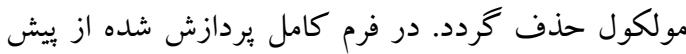
ساز P2، يروتامين P2 كمى بزر گك تر از P1 (سو آمينه اسيد در موش) است و فرم غالب در سر اسيرم بالغ است. برخلاف

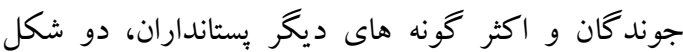

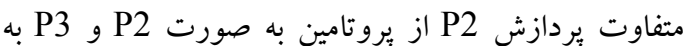

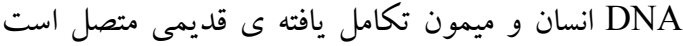
(YF) و تنها يكك شكل يُردازش شده در ميمون تكامل يافته

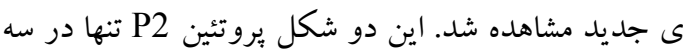

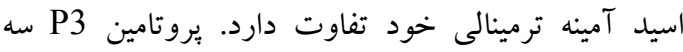
اسيدهاى آمينه از P2 كو تاه تر است و به نظر مى رسد يكى از محصولات زن P2 باشد. توالى اين يروتامين در اسبرم

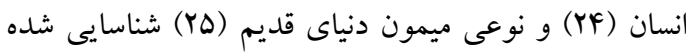
است. يروتامين P2 و P1 از اين جهت تفاوت دارند كه P2

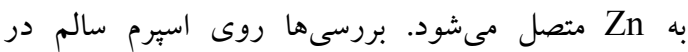
كونهاى مختلف نشان مىدهد كه يروتامين P2 انسان، موش و همستر با يك اتم Zn به مولكول متصل مى باشند.

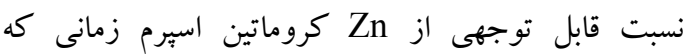


عملكرد اسيرم انسان داشته باشد و مى تواند به عنوان بيش بينى كننده بارورى در درمان هاى ART كمك شود (TV).

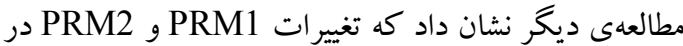
بيماران واريكوسل سبب توليد اسيرم با كمبود بروتامين بيشتر همراه است و اين يكى از دلايل احتمالى نابارورى ناشى از واريكوسل است (أl). همجنين مشاهده شد كه اله در نسبت كم P1 به ميزان قابل توجهى كاهش يافته و مقدار P2 در P1/P2 بالا به طور قابل توجهى كاهش نشان داد. مقدار ميانخين P1 mRNA در بيماران مبتلا به كاهش بيان يروتئين P1 به طور قابل توجهى بالا بود (4)). به

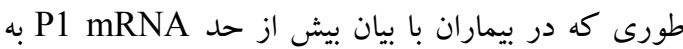

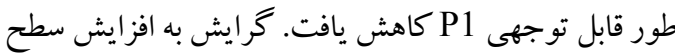

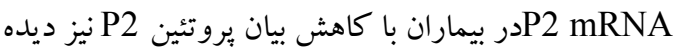

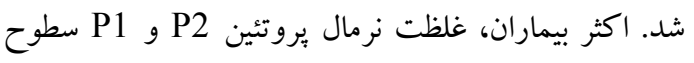

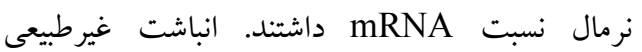

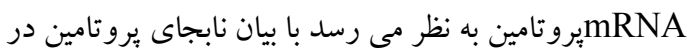

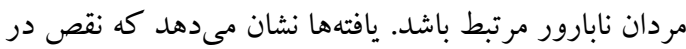

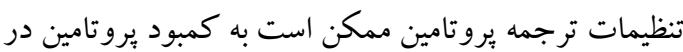

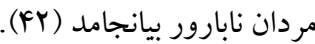

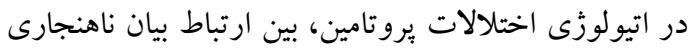

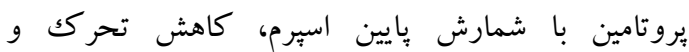

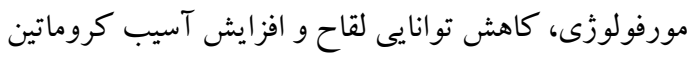

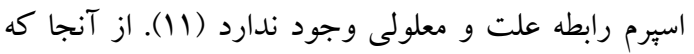

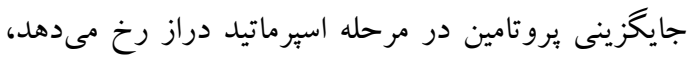

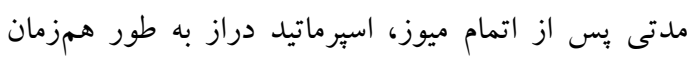

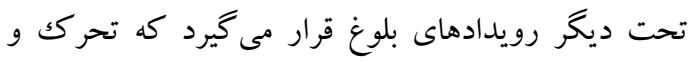

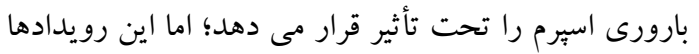

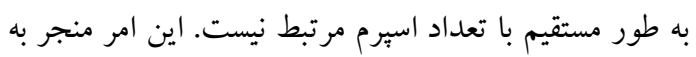

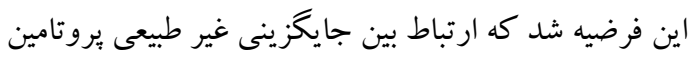
و به طور كلى كاهش كيفيت سيمن ممكن است به دليل

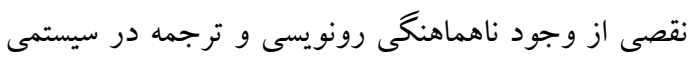

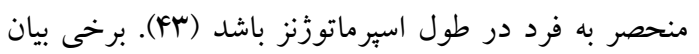

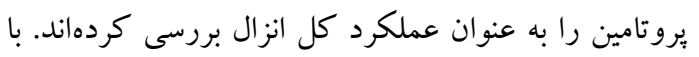

عوامل متعددى در ارتباط با بسته بندى هسته اسبرم از جمله

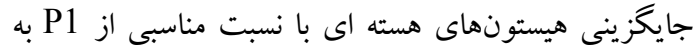
P2 و نسبت هيستون به بروتامين شناسايى شده اند از جمله تغييرات ابى زنتيك و سطوح مناسب بروتامين (·r)(·r). اين بررسىها نشان مى دهد كه نسبت غيرطبيعى P1 به P2

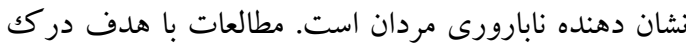
اتيولوزى نسبت غير طبيعى P1 به P2 و ظهور ايى زنتيك اسيرم و نقش احتمالى اختلالات يروتامين در ايى زنوم اسيرم نشان دادهاند كه نسبت P1 به P2 در اهداكنند كان بارور نزديك به اشناخته شده (qه, اr) و در افراد نورمواسِرمى

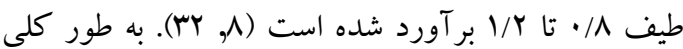
اختلال اين نسبت در هر دو حالت، با كيفيت ضعيف سيمن، افزايش آسيب DNA و كاهش بارورى مشخص شده است (r, سٓ-هاr). مطالعه ايى نشان داد بِارامترهايى از قبيل غلظت

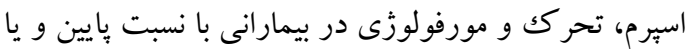
نسبت بالاى P1 به P2 در مقايسه با افرادى كه نسبت طبيعى P1 به P2 دارند، كاهش يافت (YF). علاوه بر اين، تغيير نسبت P1 به P2 با كاهش توانايى بارورى همراه است، اخر

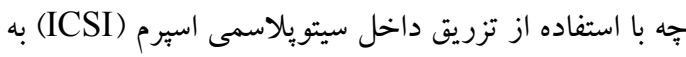

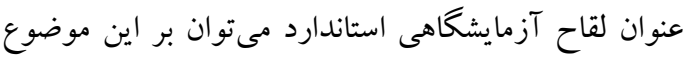
غلبه كرد (ها, צץ). استفاده از ICSI حتى در بيماران IVF با فقدان كامل P2، سبب لقاح و مورفولوزى طبيعى جنين

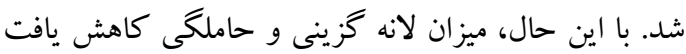

رايج ترين اختلال يروتامين در مردان نابارور، افزايش نسبت

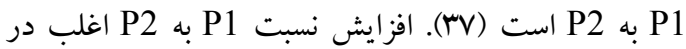
نتيجه كاهش سطح بروتئين P2 همزمان با افزايش سطح

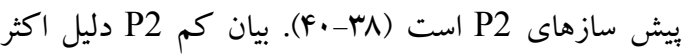

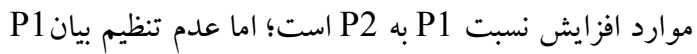

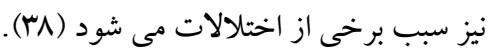

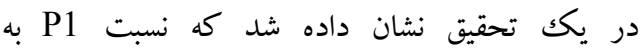

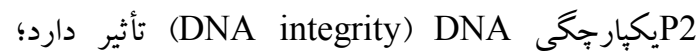
بنابر اين، مشخص شد كه مى تواند نقش مهمى در كيفيت و 
اثرات بالقوه بروتامين غيرطبيعى در جنين به حداقل رسانده

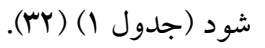

اين حال، مشخص شد كه انزال ناهمگن مى باشد و بيماران با نسبت غيرطبيعى P1 به P2 هم داراى اسرِ با وضعيت

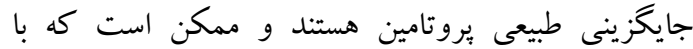
انتخاب اسيرم با مورفولوزى طبيعى براى ICSI شانس لترئس انتخاب اسيرم با يروتامين طبيعى افزايش يابد و در نتيجه

\begin{tabular}{|c|c|c|}
\hline نويسند امان & نتايج & يافته هاى مهم \\
\hline $\begin{array}{r}\text { de Yebra et } \\
\text { al. (1998) } \\
(55)\end{array}$ & 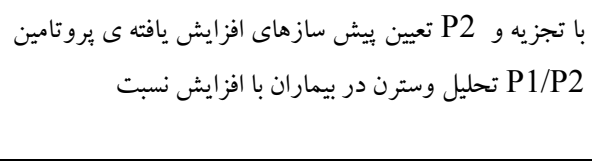 & 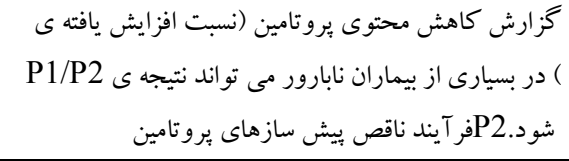 \\
\hline $\begin{array}{r}\text { Bench et } \\
\text { al. (1998) } \\
(56)\end{array}$ & در نمونه هاى بيمار به دست آمده در زمان P1/P2 نسبت & 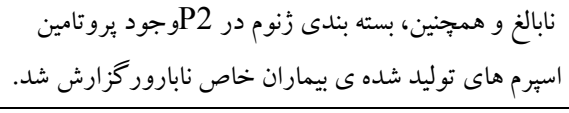 \\
\hline $\begin{array}{r}\text { Carrell et } \\
\text { al. (1999) } \\
(57)\end{array}$ & 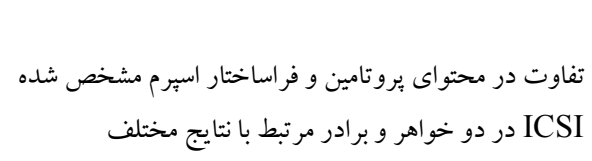 & 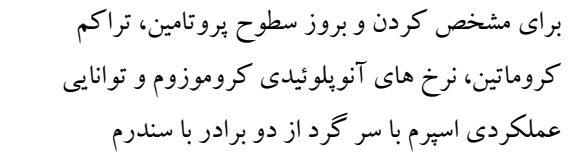 \\
\hline
\end{tabular}

Evenson et

al. (2000)

(58)

كه توسط الكتروفورز بين P2 ظهور بيش سازهاى يروتامين سم تا هب روز يس از گرماى شديد در يك بيمار تشخيص داده
تب و يا آنفلو انزا مى تو اند اثرات نهفته اى بر ساختار

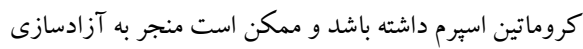

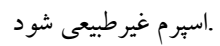

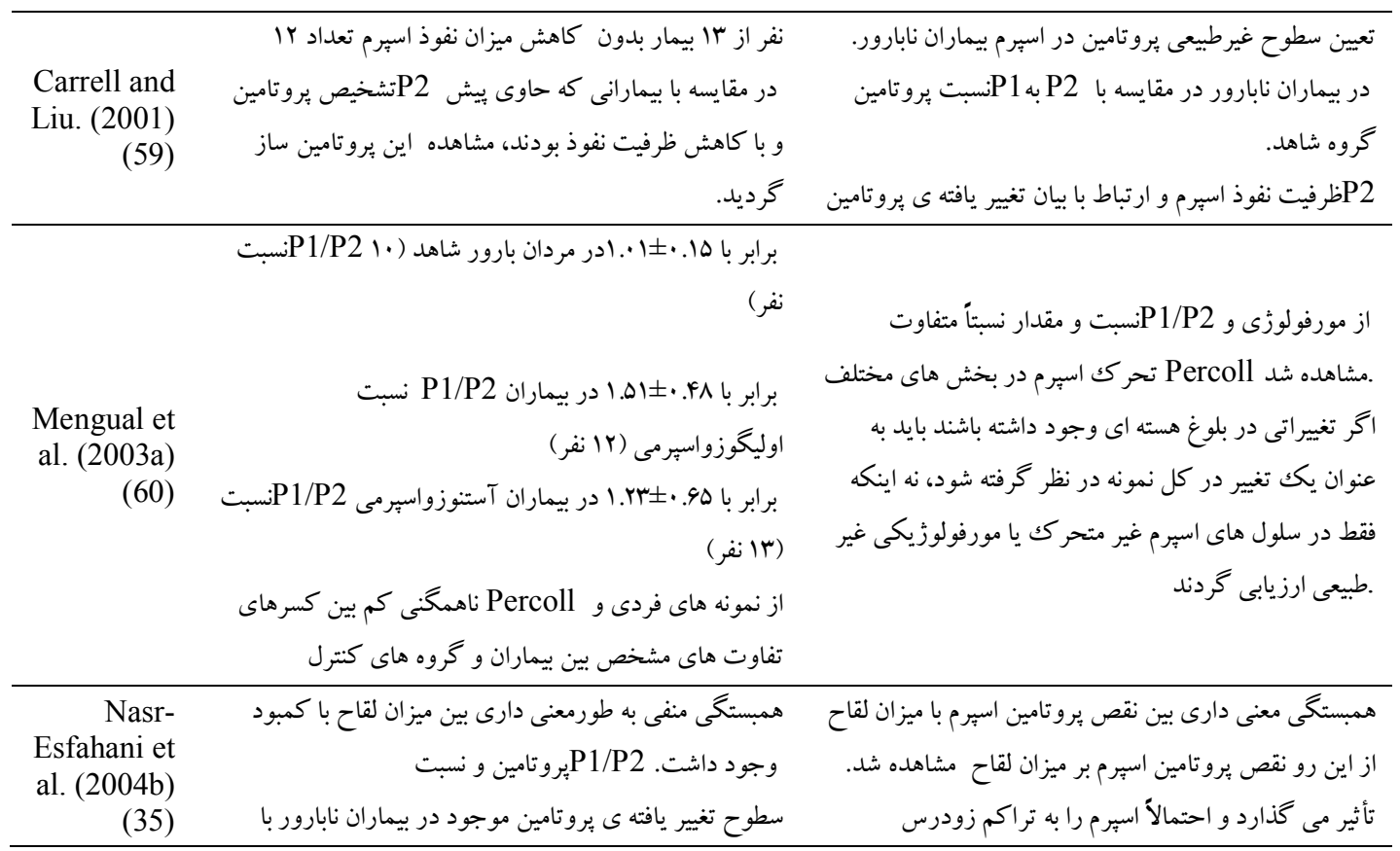




\begin{tabular}{|c|c|c|}
\hline & درمان بيمار بهبود بيدا كرد. & كروماتين يس از ICSI مستعد مى كند. \\
\hline $\begin{array}{r}\text { Aoki et al. } \\
(2005 \mathrm{a}) \\
(36)\end{array}$ & 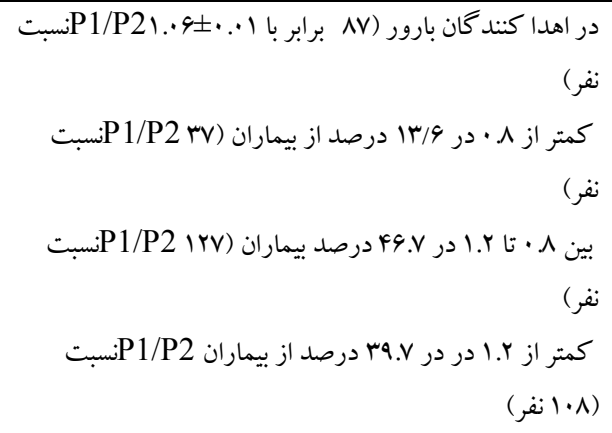 & 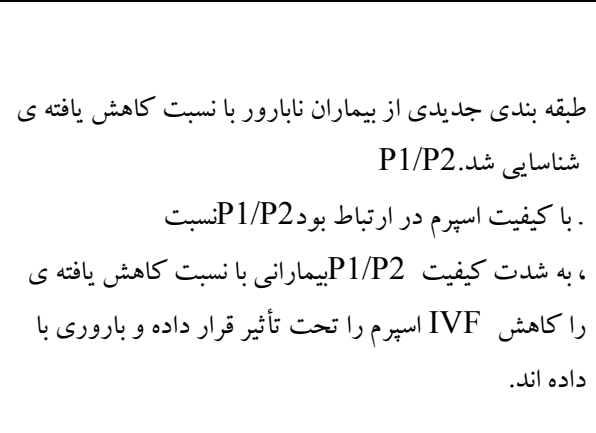 \\
\hline & با ميزان نفوذ اسبرم و ميزان لقاح2P1/P2ارتباط نسبت & \\
\hline $\begin{array}{l}\text { Aoki et al. } \\
(2005)(34)\end{array}$ & 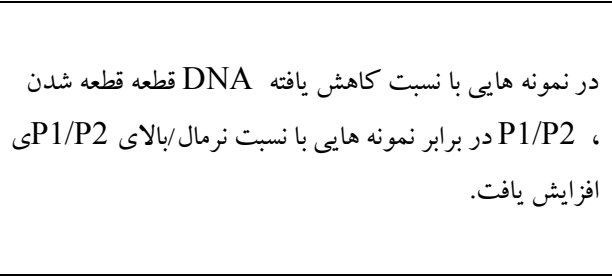 & 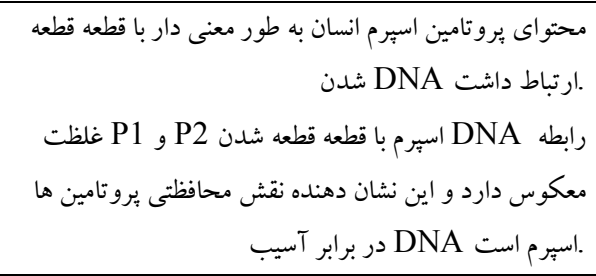 \\
\hline $\begin{array}{l}\text { Aoki et al. } \\
(2006)(42)\end{array}$ & 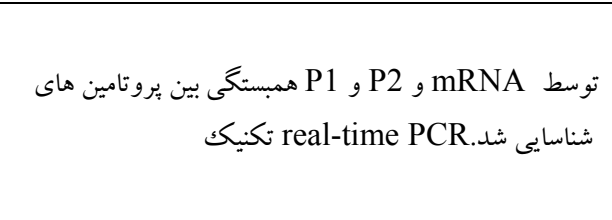 & 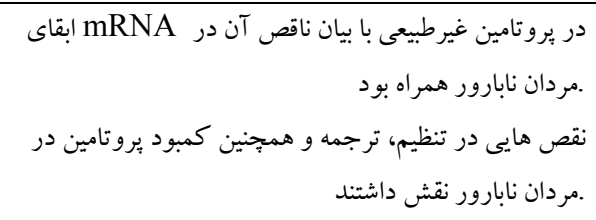 \\
\hline $\begin{array}{r}\text { Zhang et } \\
\text { al. }(2006) \\
(61)\end{array}$ & به يروتامين در مردان نابارور افزايش يافت.2Bنسبت هيستون & 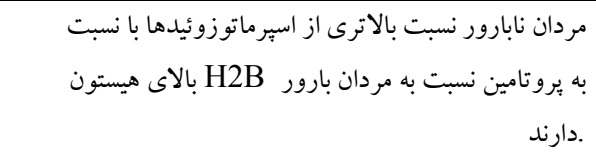 \\
\hline $\begin{array}{r}\text { Torregrosa } \\
\text { et al. } \\
(2006)(40)\end{array}$ & 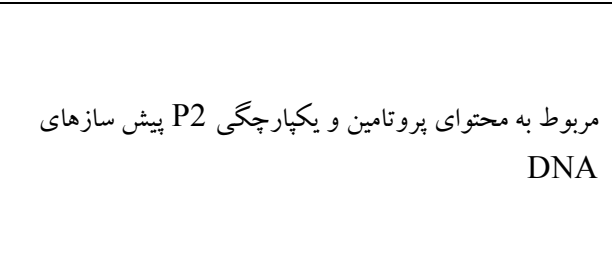 & 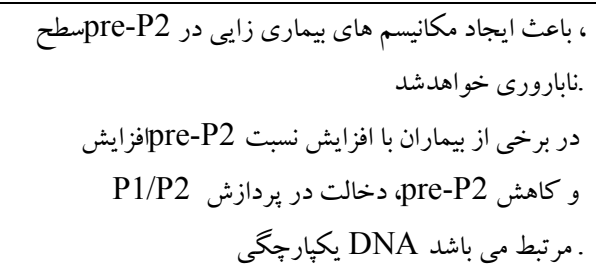 \\
\hline $\begin{array}{r}\text { Tuttelmann } \\
\text { et al. } \\
(2010)(62)\end{array}$ & 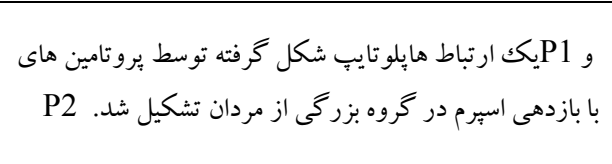 & 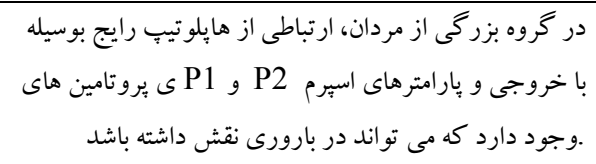 \\
\hline $\begin{array}{l}\text { Garcia- } \\
\text { Peiro et al. } \\
(2011)(38)\end{array}$ & 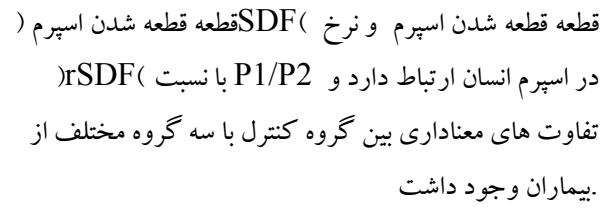 & 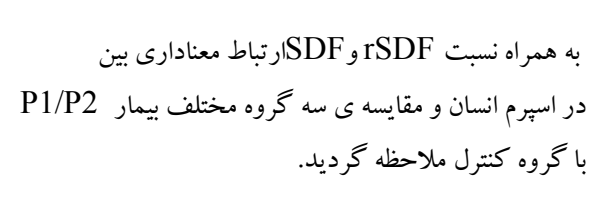 \\
\hline $\begin{array}{l}\text { Jiang et al. } \\
(2017)(63)\end{array}$ & 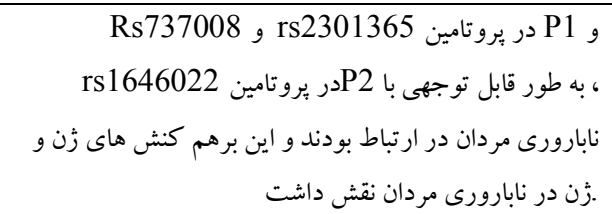 & 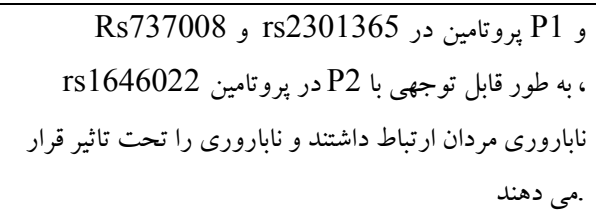 \\
\hline $\begin{array}{r}\text { Amor et al. } \\
(2018)\end{array}$ & ارتباط DNA شاخص قطعه قطعه شدن P1/P2 نسبت & را تحت تأثير قرار داده و DNA يكيارجخى P1/P2 نسبت \\
\hline
\end{tabular}

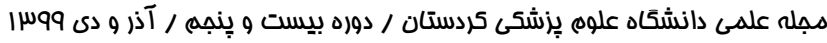




\begin{tabular}{|c|c|c|}
\hline & 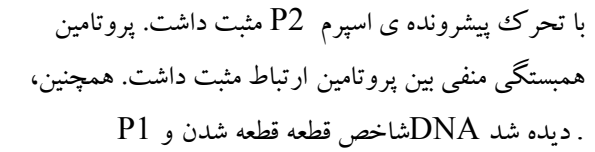 & 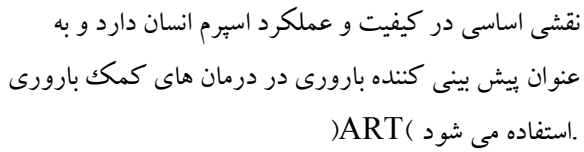 \\
\hline $\begin{array}{r}\text { Hamad et } \\
\text { al. (2019) } \\
(49)\end{array}$ & 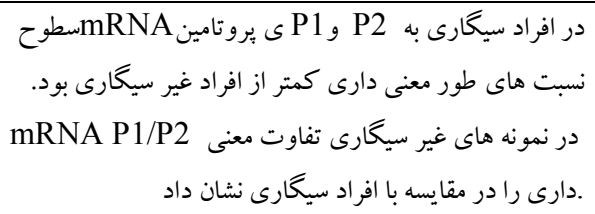 & 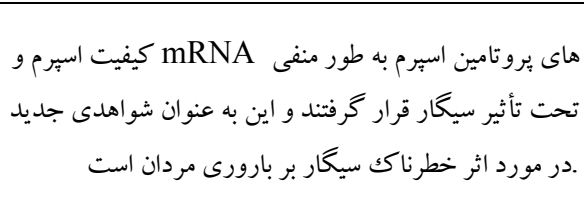 \\
\hline
\end{tabular}

Hamidian

et al.

(2020) (15)

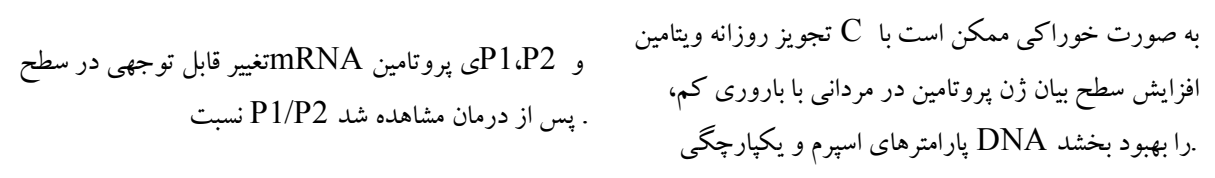

بروتامين ا ممكن است باعث اتصال غيرطبيعى يكك عامل

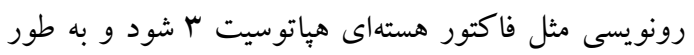

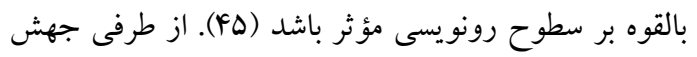

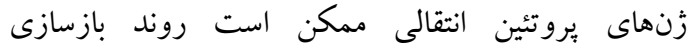

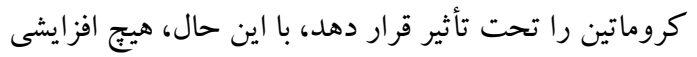
در تغييرات زن مردان نابارور و يا مردانى با ناهنجارى

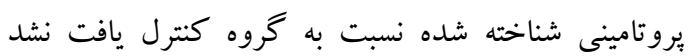

فر آيند باز آرايى اتصال يُروتامين به كروماتين نيازمند زمان رونويسى DNA و ترجمه mRNA در اسبرماتيد در حال تكامل است (FV). يكك مكانيسم براى انجام تنظيمات، حفظ هRNA سلولى جدا مىشوند. عامل مكانيسم سركوب كنندهى ترجمه شناخته نشده است، با اين حال، روشن است كه كه

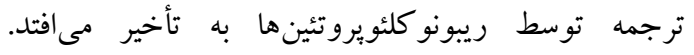
(RBPs) RNA ها به بروتئين هاى اتصالى به متصل مى شوند و اين كميلكس mRNA تا زمان ايجاد

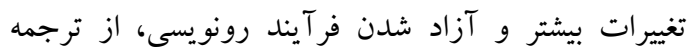

$$
\text { جلو كيرى مى كند (FN). (F). }
$$

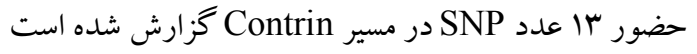

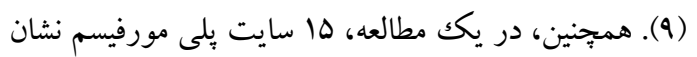

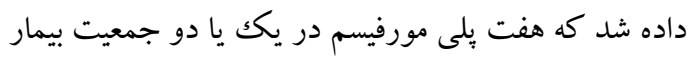

Single Nucleotide (SNP) تجزيه و تحليل Polymorphism

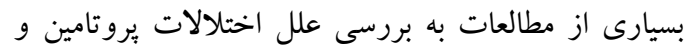

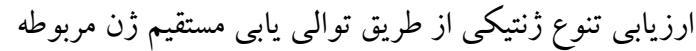

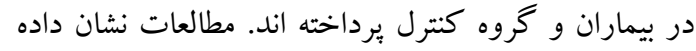
اند كه نواحى كد كننده يروتامين و يروتئين انتقالى در هر گونه سبب اختلالات در بيماران نمىشوند (F) (FF). محققان مشخص كردند توالى نواحى غير ترجمه شونده يروتامين ا و Y ممكن است رونويسى بروتامين، ترجمه و

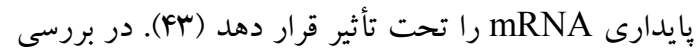
مقايسهى طولى VLR (Variable Length Repeat) به

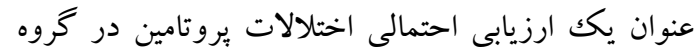

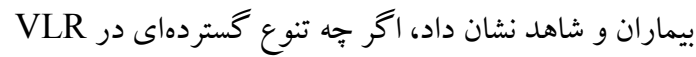

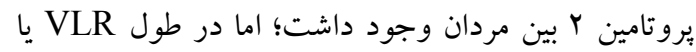

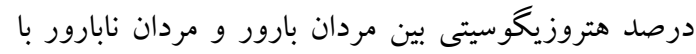

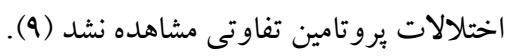
very low frequency of ) هر كانس وايين SNP (SNPs

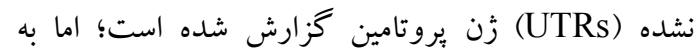

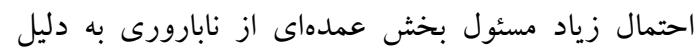

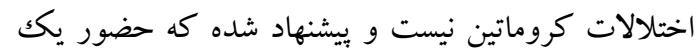

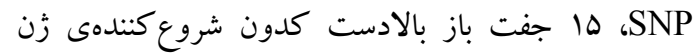




$$
\text { نو كلئوهيستون در ساختار كروماتين اسبرم: }
$$

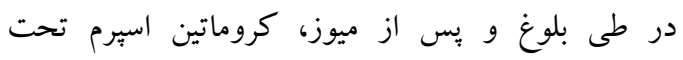

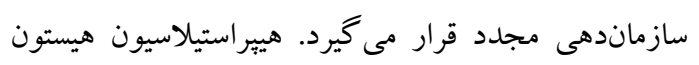

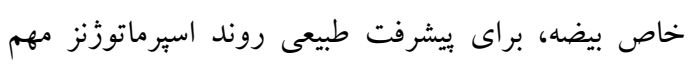
است و توسط فعلوانفعالات هيستون استيل ترانسفرازها و

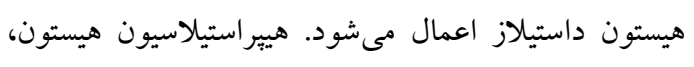

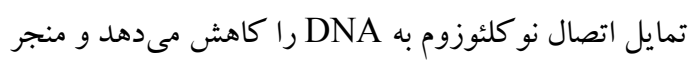

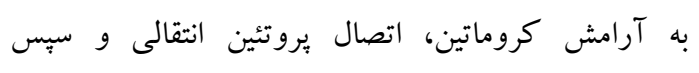

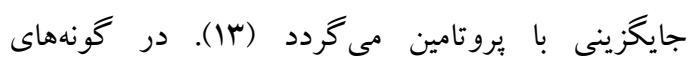
يستانداران از جمله انسان، برخى هيستون ها در كروماتين بئن

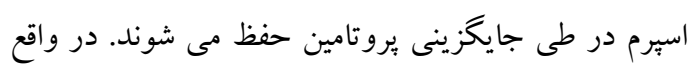

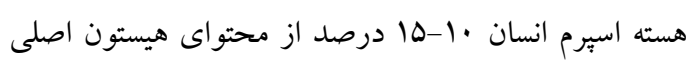

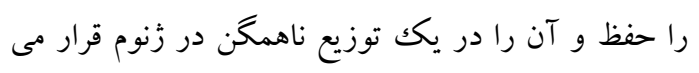
دهد (•). نسبت مناسب هيستون

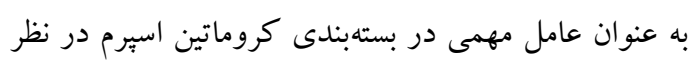

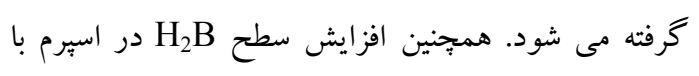

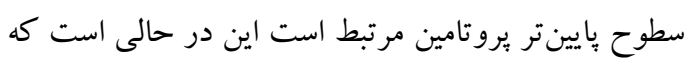
سطح بالايى از ذخيرهى هيستون در اسبرم برخى از بيماران

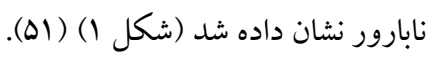

نسبت به گروه كنترل فركانس بالاترى داشتهاند. از اين هفت بلى مورفيسم، دو تاى آن ها منجر به تعويض اسيد آمينه در دومين به شدت حفاظت شده cold shock (مورد نياز براى فعاليت رونويسى) بود و يكى منجر به تغيير بسيار

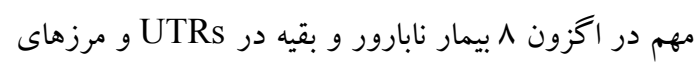

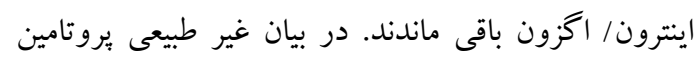

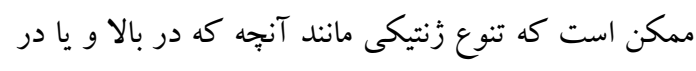

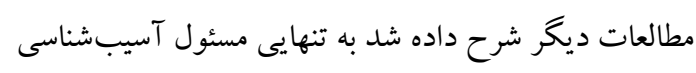

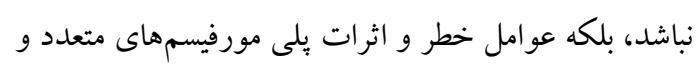

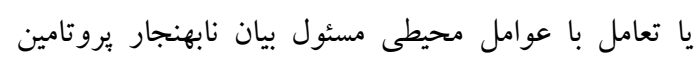

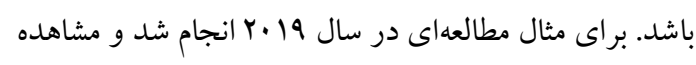

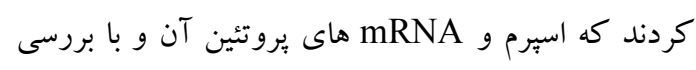

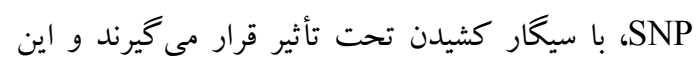

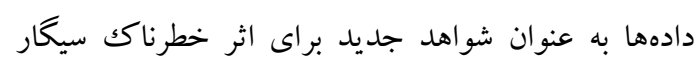

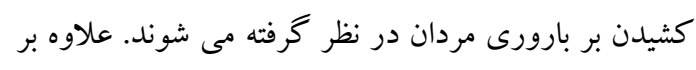

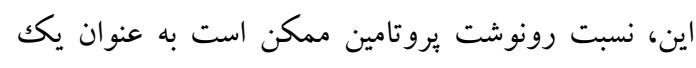
نشانخر براى بارورى مردان باشد (Fq).

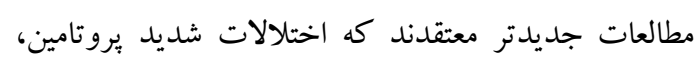
آزواسبرمى و يا اليكواسبرمى شديد ممكن است با افزايش

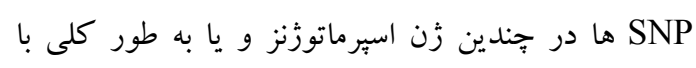

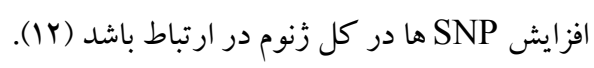

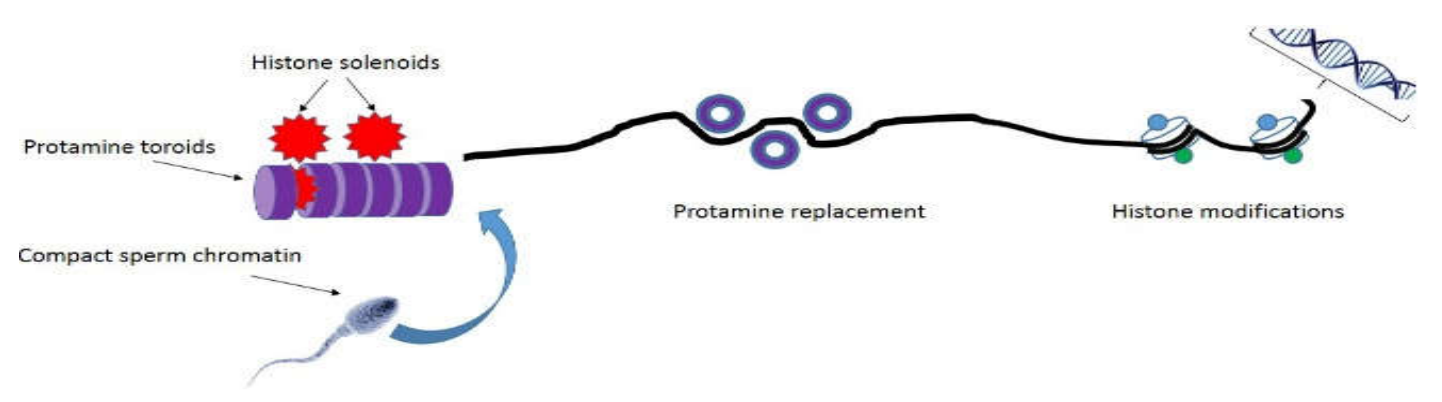

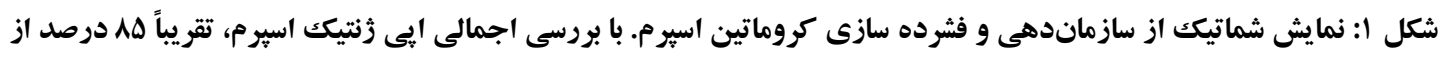

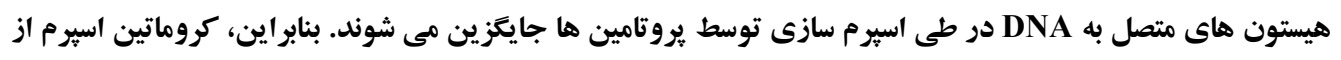

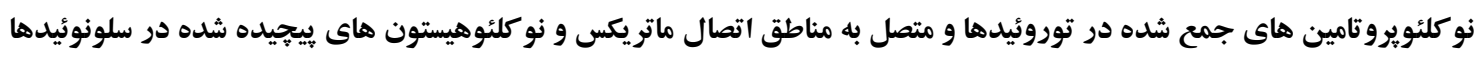

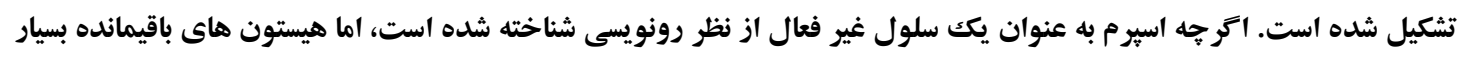

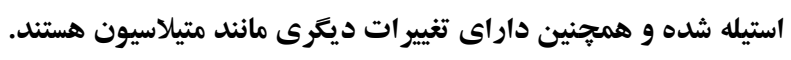

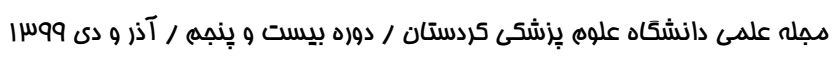


نقص يروتامين از گروه كنترل تفاوت دارد. جالب است كه

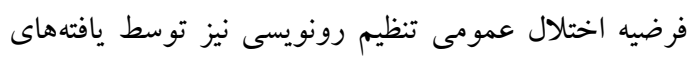

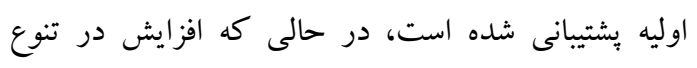

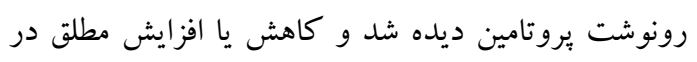

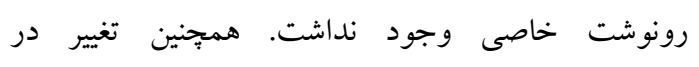

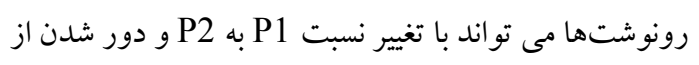
وضعيت طبيعى همراه باشد (هF).

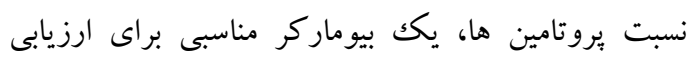

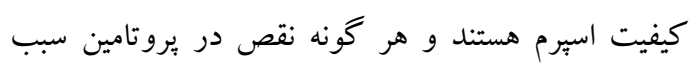

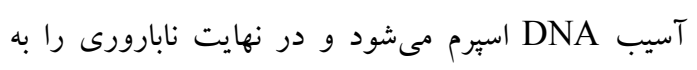
دنبال خواهد داشت. هر دو يروتامين P1 و P2 براى متراكم كردن كروماتين اسبرم ضرورى هستند و كمبود هر كدام از اين دو سبب آسيب DNA ى اسبرم و مركى جنين مى شود.

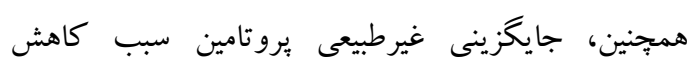

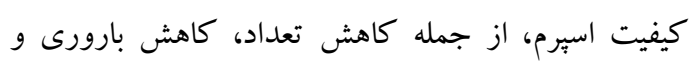

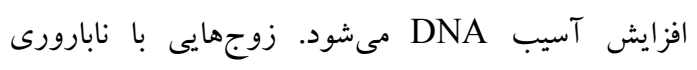
ناشناخته، نقص مشخصى در نسبت غير طبيعى P1/P2 دارند.

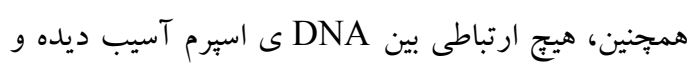

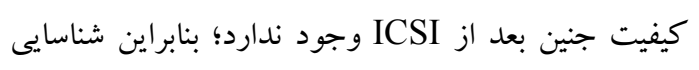
آسيب DNA اسيرم جهت درمان اين بيماران مىتواند كمك زيادى در رفع اين مشكل كند. تحقيقات در زمينهى

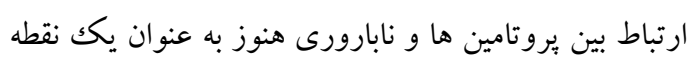

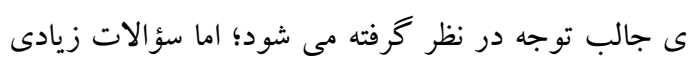

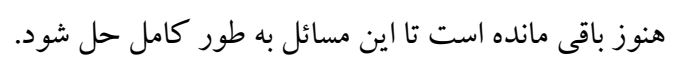

\section{تشكر و قدردانى}

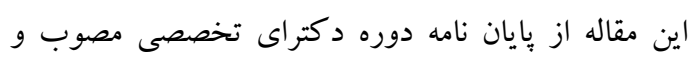

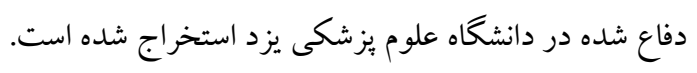

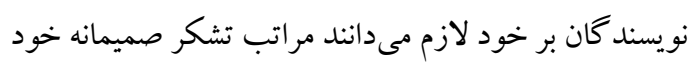

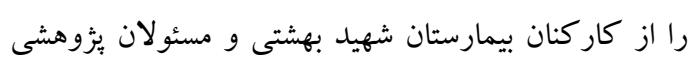

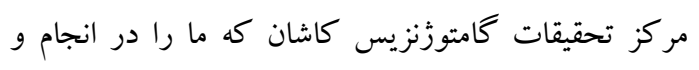
ارتقاء كيفى اين يثوهش يارى دادند، اعلام نمايند
بيان زن در اسبرم:

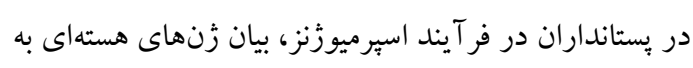

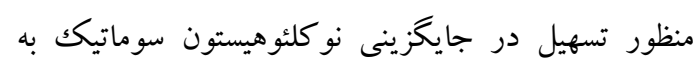

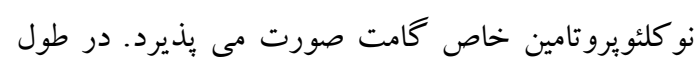

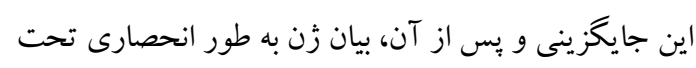

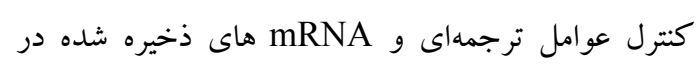

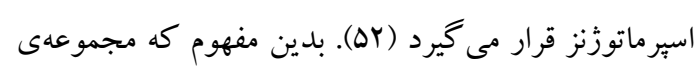

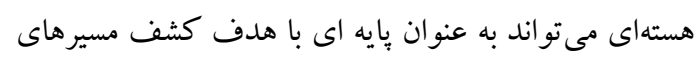
بيان زن در اسبرم مردان نابارور استفاده شود. يردازش RNA در سلولهاى زايا: فر آيند رونويسى در اسبرماتوسيت ها، در سطح بالايى فعال

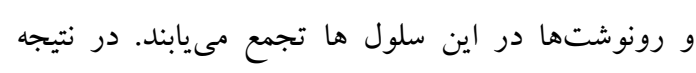

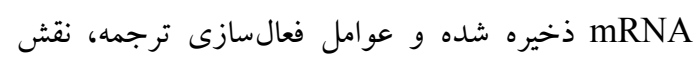

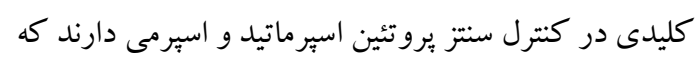
در مراحل آخر بلوغ سلول هاى زرمينال توليد مى شوند

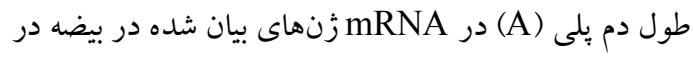

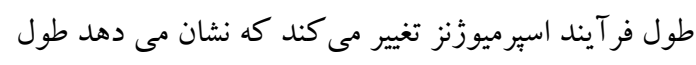
اين توالى ممكن است ترجمه mRNA را تحت تأثير قرار

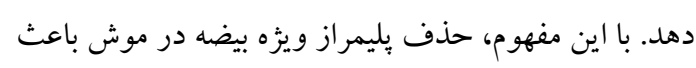

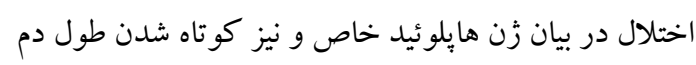
يلى mRNA (A) مىشود. بسيارى از mRNA ها ماند يروتامين و رونوشت يروتئين انتقالى، در اسبرماتيد اوليه به ديه

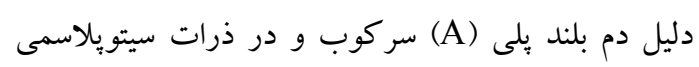

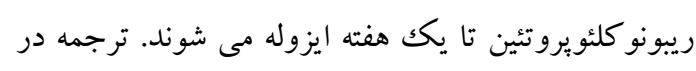

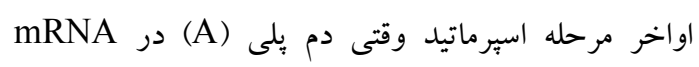

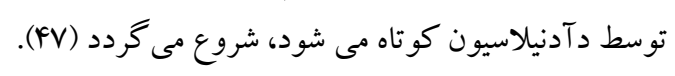

\section{نتيجه كيرى}

تنظيم بروتامين از ديخر تنظيم گرهاى ترجمه اى رونوشتها

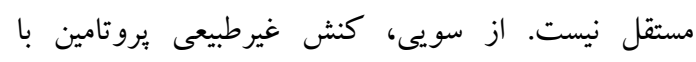

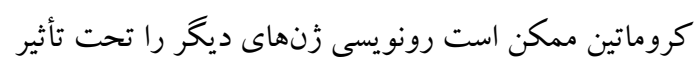

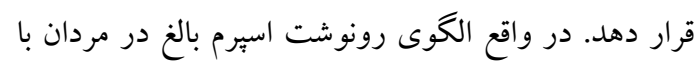


1.Griswold MD. Spermatogenesis: the commitment to meiosis. Physiol Rev. 2015; 96(1):117.

2.Khalili MA, Aghaie-Maybodi F, Anvari M, Talebi AR. Sperm nuclear DNA in ejaculates of fertile and infertile men: correlation with semen parameters. Urol J. 2009; 3(3):154-9.

3.Rahiminia T, Yazd EF, Fesahat F, Moein MR, Mirjalili AM, Talebi AR. Sperm chromatin and DNA integrity, methyltransferase mRNA levels, and global DNA methylation in oligoasthenoteratozoospermia. Clin Exp Reprod Med. 2018; 45(1):17-24.

4.Wykes SM, Krawetz SA. Conservation of the PRM1 $\rightarrow$ PRM2 $\rightarrow$ TNP2 domain. DNA Sequence. 2003; 14(5):359-67.

5.Balhorn R. The protamine family of sperm nuclear proteins. Genome Biol. 2007; 8(9):227.

6.Pardede BP, Agil M, Supriatna I. Protamine and other proteins in sperm and seminal plasma as molecular markers of bull fertility. Vet World. 2020; 13(3):556-62.

7.Bao J, Bedford MT. Epigenetic regulation of the histone-to-protamine transition during spermiogenesis. Reproduction. 2016; 151(5):55-70.

8.Aoki VW, Liu L, Jones KP, Hatasaka HH, Gibson M, Peterson CM, et al. Sperm protamine 1/protamine 2 ratios are related to in vitro fertilization pregnancy rates and predictive of fertilization ability. Fertil Steril. 2006; 86(5):1408-15.

9.Hammoud S, Emery BR, Aoki VW, Carrell DT. Identification of genetic variation in the 5' and $3^{\prime}$ non-coding regions of the protamine genes in patients with protamine deregulation. Arch Androl. 2007; 53(5):267-74.

10.Agarwal A, Mulgund A, Hamada A, Chyatte MR. A unique view on male infertility around the globe. Reprod Biol Endocrinol. 2015; 13(1):37.

11. Castillo J, Simon L, de Mateo S, Lewis S, Oliva R. Protamine/DNA ratios and DNA damage in native and density gradient centrifuged sperm from infertile patients. $\mathrm{J}$ Androl. 2011; 32(3):324-32.

12.Carrell DT. The genetics of male infertility in the era of genomics. The genetics of male infertility: Springer; 2007. p. 3-27.

13. Miller D, Brinkworth M, Iles D. Paternal DNA packaging in spermatozoa: more than the sum of its parts? DNA, histones, protamines and epigenetics. Reproduction. 2010; 139(2):287-301.

14.Grzmil P, Boinska D, Kleene KC, Adham I, Schlüter G, Kämper M, et al. Prm3, the fourth gene in the mouse protamine gene cluster, encodes a conserved acidic protein that affects sperm motility. Biol Reprod. 2008; 78(6):958-67.

15.Hamidian S, Talebi AR, Fesahat F, Bayat M, Mirjalili AM, Ashrafzadeh HR, et al. The effect of vitamin $\mathrm{C}$ on the gene expression profile of sperm protamines in the male partners of couples with recurrent pregnancy loss: A randomized clinical trial. Clin Exp Reprod Med. 2020; 47(1):68-76.

16.Rahimipour M, Talebi AR, Anvari M, Sarcheshmeh AA, Omidi M. Effects of different doses of ethanol on sperm parameters, chromatin structure and apoptosis in adult mice. Eur $\mathrm{J}$ Obstet Gynecol. 2013; 170(2):423-8.

17. Schluter G, Engel W. The rat Prm3 gene is an intronless member of the protamine gene cluster and is expressed in haploid male germ cells. Cytogenet Genome Res. 1995; 71(4):352-5.

18.Corzett M, Mazrimas J, Balhorn R. Protamine 1: protamine 2 stoichiometry in the sperm of eutherian mammals. Mol Reprod. Dev. 2002; 61(4):519-27. 
19.Schrider DR, Navarro FC, Galante PA, Parmigiani RB, Camargo AA, Hahn MW, et al. Gene copy-number polymorphism caused by retrotransposition in humans. PLoS Genet. 2013; 9(1):e1003242.

20.Seligman J, Zipser Y, Kosower NS. Tyrosine phosphorylation, thiol status, and protein tyrosine phosphatase in rat epididymal spermatozoa. Biol Reprod. 2004; 71(3):1009-15.

21.Luke L, Tourmente M, Roldan ER. Sexual selection of protamine 1 in mammals. Mol Biol Evol. 2015; 33(1):174-84.

22.Akmal M, Widodo MA, Sumitro SB, Purnomo BB. The important role of protamine in spermatogenesis and quality of sperm: A mini review. Asian Pac J Reprod. 2016; 5(5):35760 .

23.Oliva R. Protamines and male infertility. Hum Reprod Update. 2006; 12(4):417-35.

24.Liu L, Aston KI, Carrell DT. Protamine extraction and analysis of human sperm protamine 1/protamine 2 ratio using Acid gel electrophoresis. Spermatogenesis: Springer; 2013. p. 445-50.

25.Balhorn R. Mammalian protamines: structure and molecular interactions. Molecular biology of chromosome function: Springer; 1989. p. 366-95.

26.Bjorndahl L, Kvist U. Human sperm chromatin stabilization: a proposed model including zinc bridges. Mol Hum Reprod. 2009; 16(1):23-9.

27. Cho C, Jung-Ha H, Willis WD, Goulding EH, Stein P, Xu Z, et al. Protamine 2 deficiency leads to sperm DNA damage and embryo death in mice. Biol Reprod. 2003; 69(1):211-7.

28.Rahiminia T, Hosseini A, Anvari M, Ghasemi-Esmailabad S, Talebi AR. Modern human sperm freezing: effect on DNA, chromatin and acrosome integrity. Taiwan J Obstet Gynecol. 2017; 56(4):472-6.

29.Carrell DT, Emery BR, Hammoud S. Altered protamine expression and diminished spermatogenesis: what is the link? Hum Reprod Update. 2007; 13(3):313-27.

30.Gunes S, Kulac T. The role of epigenetics in spermatogenesis. Turk J Urol. 2013; 39(3):181-7.

31.Aleem M, Padwal V, Choudhari J, Balasinor N, Gill $\square$ Sharma M. Sperm protamine levels as indicators of fertilising potential in sexually mature male rats. Andrologia. 2008; 40(1):2937.

32.Aoki VW, Emery BR, Liu L, Carrell DT. Protamine levels vary between individual sperm cells of infertile human males and correlate with viability and DNA integrity. J Androl. 2006; 27(6):890-8.

33. Mohammad HN-E, Mohammad S, Shahnaz R, Maryam A, Shahla R, Fariba M, et al. Effect of sperm DNA damage and sperm protamine deficiency on fertilization and embryo development post-ICSI. Reprod Biomed Online. 2005; 11(2):198-205.

34.Aoki VW, Moskovtsev SI, Willis J, Liu L, Mullen JBM, Carrell DT. DNA integrity is compromised in protamine-deficient human sperm. J Androl. 2005; 26(6):741-8.

35.Nasr-Esfahani MH, Razavi S, Mozdarani H, Mardani M, Azvagi H. Relationship between protamine deficiency with fertilization rate and incidence of sperm premature chromosomal condensation post-ICSI. Andrologia. 2004; 36(3):95-100.

36.Aoki VW, Liu L, Carrell DT. Identification and evaluation of a novel sperm protamine abnormality in a population of infertile males. Hum Reprod. 2005; 20(5):1298-306.

37.Amor H, Zeyad A, Sobhy Bakry M, Bosilah AMH, Ben Ali H, Eid Hammadeh M. Protamine Ratio as Predictor of the Fertility Potential of Sperm by Couple Undergoing ICSI. Int J Women's Health Reprod Sci. 2018; 6(4):400-9. 
38.Garcia-Peiro A, Martinez-Heredia J, Oliver-Bonet M, Abad C, Amengual MJ, Navarro J, et al. Protamine 1 to protamine 2 ratio correlates with dynamic aspects of DNA fragmentation in human sperm. Fertil Steril. 2011; 95(1):105-9.

39.Evgeni E, Charalabopoulos K, Asimakopoulos B. Human sperm DNA fragmentation and its correlation with conventional semen parameters. J Reprod Infertil. 2014; 15(1):2.

40.Torregrosa N, Domínguez-Fandos D, Camejo MI, Shirley CR, Meistrich ML, Ballescà JL, et al. Protamine 2 precursors, protamine 1/protamine 2 ratio, DNA integrity and other sperm parameters in infertile patients. Hum Reprod. 2006; 21(8):2084-9.

41.Nayeri M, Talebi AR, Heidari MM, Seifati SM, Tabibnejad N. Polymorphisms of sperm protamine genes and CMA3 staining in infertile men with varicocele. Rev Int Androl. 2020; 18(1):7-13.

42.Aoki VW, Liu L, Carrell DT. A novel mechanism of protamine expression deregulation highlighted by abnormal protamine transcript retention in infertile human males with sperm protamine deficiency. Mol Hum Reprod. 2006; 12(1):41-50.

43. Carrell DT, Emery BR, Hammoud S. The aetiology of sperm protamine abnormalities and their potential impact on the sperm epigenome. Int J Androl. 2008; 31(6):537-45.

44.Aoki VW, Christensen GL, Atkins JF, Carrell DT. Identification of novel polymorphisms in the nuclear protein genes and their relationship with human sperm protamine deficiency and severe male infertility. Fertil Steril. 2006; 86(5):1416-22.

45.Ravel C, Chantot-Bastaraud S, El Houate B, Berthaut I, Verstraete L, De Larouziere V, et al. Mutations in the protamine 1 gene associated with male infertility. Mol Hum Reprod. 2007; 13(7):461-4.

46.O'Brien KLF, Varghese AC, Agarwal A. The genetic causes of male factor infertility: a review. Fertil Steril. 2010; 93(1):1-12.

47.Champroux A, Torres-Carreira J, Gharagozloo P, Drevet J, Kocer A. Mammalian sperm nuclear organization: resiliencies and vulnerabilities. Basic Clin Androl. 2016; 26(1):17.

48. Gendelman M, Roth Z. Seasonal effect on germinal vesicle-stage bovine oocytes is further expressed by alterations in transcript levels in the developing embryos associated with reduced developmental competence. Biol Reprod. 2012; 86(1):1-9.

49.Hamad M, Shelko N, Montenarh M, Hammadeh ME. The impact of cigarette smoking on protamines 1 and 2 transcripts in human spermatozoa. Hum Fertil. 2019; 22(2):104-10.

50.La Spina FA, Romanato M, Brugo-Olmedo S, De Vincentiis S, Julianelli V, Rivera RM, et al. Heterogeneous distribution of histone methylation in mature human sperm. J Assist Reprod Genet. 2014; 31(1):45-9.

51.Yu B, Qi Y, Liu D, Gao X, Chen H, Bai C, et al. Cigarette smoking is associated with abnormal histone-to-protamine transition in human sperm. Fertil Steril. 2014; 101(1):51-7.

52.Sharma R, Agarwal A. Spermatogenesis: an overview. Sperm Chromatin: Springer; 2011. p. $19-44$.

53.Hammoud SS, Nix DA, Zhang H, Purwar J, Carrell DT, Cairns BR. Distinctive chromatin in human sperm packages genes for embryo development. Nature. 2009; 460(7254):473-8.

54.Qujeq D. Evaluation of protamine level in human sperm samples using chromomycin a3 and aniline blue staining. Res Mol Med. 2016; 4(1):50-5.

55.de Yebra Ls, Ballesca J-L, Vanrell JA, Corzett M, Balhorn R, Oliva R. Detection of P2 Precursors in the Sperm Cells of Infertile Patients Who Have Reduced Protamine P2 Levels 5. Fertil Steril. 1998; 69(4):755-9.

56.Bench G, Corzett M, De Yebra L, Oliva R, Balhorn R. Protein and DNA contents in sperm from an infertile human male possessing protamine defects that vary over time. Mol Reprod Dev. 1998; 50(3):345-53.

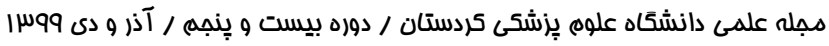


57.Carrell DT, Emery BR, Liu L. Characterization of aneuploidy rates, protamine levels, ultrastructure, and functional ability of round-headed sperm from two siblings and implications for intracytoplasmic sperm injection. Fertil Steril. 1999; 71(3):511-6.

58.Evenson DP, Jost LK, Corzett M, Balhorn R. Characteristics of human sperm chromatin structure following an episode of influenza and high fever: a case study. J Androl. 2000; 21(5):739-46.

59.Carrell DT, Liu L. Altered protamine 2 expression is uncommon in donors of known fertility, but common among men with poor fertilizing capacity, and may reflect other abnormalities of spermiogenesis. J Androl. 2001; 22(4):604-10.

60.Mengual L, Ballescá JL, Ascaso C, Oliva R. Marked differences in protamine content and $\mathrm{P} 1 / \mathrm{P} 2$ ratios in sperm cells from percoll fractions between patients and controls. $\mathrm{J}$ Androl. $2003 ; 24(3): 438-47$.

61.Zhang X, Gabriel MS, Zini A. Sperm nuclear histone to protamine ratio in fertile and infertile men: evidence of heterogeneous subpopulations of spermatozoa in the ejaculate. $\mathrm{J}$ Androl. 2006; 27(3):414-20.

62.Tuttelmann F, Krenkova P, Romer S, Nestorovic A, Ljujic M, Stambergova A, et al. A common haplotype of protamine 1 and 2 genes is associated with higher sperm counts. Int $\mathbf{J}$ Androl. 2010; 33(1):240-8.

63.Jiang W, Zhu P, Zhang J, Wu Q, Li W, Liu S, et al. Polymorphisms of protamine genes contribute to male infertility susceptibility in the Chinese Han population. Oncotarget. 2017; 8(37):61637-45. 